To cite this article: Vera N. Okonoko \& Ufuoma Eruvwe (2021) Utilization of Information and Communication Technology Based Information Resources in Library User Education Programmes: A Study of Colleges of Education in South-South, Nigeria. Information Impact: Journal of Information and Knowledge Management, 12:1, 76-87, DOI: https://dx.doi.org/10.4314/iijikm.v12i1.6

To link to this article: https://dx.doi.org/10.4314/iijikm.v12i1.6

\title{
Utilization of Information and Communication Technology Based Information Resources in Library User Education Programmes: A Study of Colleges of Education in South- South, Nigeria
}

\author{
${ }^{1}$ Vera Ngozi Okonoko \\ ${ }^{2}$ Ufuoma Eruvwe \\ ${ }^{1}$ College of Education Library, Agbor, Nigeria \\ ${ }^{2}$ Federal University of Petroleum Resources Library, Effurun, Nigeria
}

\begin{abstract}
The study investigated utilization of information and communication technology-based information resources in library user education programmes in South-South Nigeria. Four research questions and one hypothesis guided the study. Descriptive survey research design was adopted for the study. The population of the study comprised 1022 respondents which consist of 62 staff and 960 library users. The instrument for data collection was questionnaire of a four-point rating scale and observation checklist. Tools used for data analysis of research questions were frequency, percentage, mean and standard deviation; t-test was used to test the null hypothesis at selected probability of 0.05 level significance. The findings revealed that the ICT facilities available are limited for effective utilization of ICT-based information resources in library user education programmes. The study reveals that ICT-based resources listed in the table were utilized to high extent in SouthSouth colleges of education libraries for user education programmes. It also shows that poor funding was the major challenge of utilization of ICT-based resources for user education programmes in colleges of education libraries under study.
\end{abstract}

Keywords: Technology, Information Resources, User Education, College Libraries

CONTACT Vera N. Okonoko and Ufuoma Eruvwe eromoserecon@yahoo.comi Federal University of Petroleum Resources Library, Effurun, Nigeria.

2021 The Authors Published with License by Information Impact

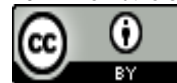




\section{Introduction}

The aim of establishing the library is for the library users to utilize the information resources in it. Library users make use of the library through research, reading and self development. According to Atinmo (2000), utilization is the ability to make effective and independent use of resources and services. This implies that the materials are to be in the appropriate format and language for use. It also extends to the frequency of usage of the materials, services and the concomitant utility derived from the resources as observed by Adebayo (2007). Examples of such resources and services are the library resources and services. The word library comes from the Latin word Liber, which means book. So the traditional definition of the library is a place where books are kept for the purpose of reading and study. However, this definition seems inappropriate these days, as libraries, now unlike earlier libraries in addition to books, contain other resources that can inform, communicate or educate. Such resources are audio visual materials, examples of which are; computers, Internet, telecommunication technologies, e.tc. Resources such as journals, magazines, newspapers, pamphlets and recreational resources are also found in the library. Furthermore, Clarke (2009) defined the library as an institution that acquires, organizes, preserves and makes available the recorded knowledge of man to users. He also sees it as a collection of books and non-book materials organized and kept for reading, studying and consultation. Librarians have to be on ground and to instruct the users on how to use the library; they have to familiarize the students with the techniques of the library use and information retrieval. This could be achieved with the user education programme.

User education refers to a well-planned programme of training and education of patrons on the skills and techniques of locating, retrieving and utilizing of library materials. User education, therefore, is the training given to a library user to make him or her, an effective user of the library. To be relevant, therefore, academic libraries must be user-friendly by ensuring effective use of the resources with minimal difficulties. This can only be possible, with a wellplanned and meticulously executed user education programme, which according to Edoka (2000), is the art of educating the patron, whether student, librarian or member of the public on how best to make use of the overall resources of the library. Similarly, Zodwa (2013) opined that library user education is a programme that is offered to first year students, an introduction to the library's resources as well as information on study skills and academic integrity to help to make their first year experience successful. The programme falls under the umbrella of information literacy and is designed to educate students, faculty and librarian in locating and using appropriate print or online resources for their research, assignments, and the introduction of information and communication technology uses in the libraries is paramount.

Information and Communication Technology (ICT) utilization in libraries, especially academic libraries has continued to revolutionize the pattern and scope of library services with the introduction of the use of ICT into library user education programme. ICT is a generic term that refers to technologies which are being used for collection, storing, editing and passing on information in various forms. Tinio (2002) defined ICT-Based as a diverse set of technological tools and resources such as computers, Internet, broadcasting technologies (radio and television) that communicate, create, disseminate, store and manage information while ICT-based resources encompass any medium for recording information (magnetic disk, tape, optical disks (CD/DVD), flash and using communication through voice and sound or images, microphones, cameras, loudspeakers, telephone to cellular phones. It includes the wide variety of computing hardware (Desktop computers, laptops, server, mainframes, and network storage). The use of ICT for library user education programme has lots of potentials, which are, to enable library users make effective use of the library, to train students in skills which they will need in further education and 
as ongoing learning process throughout the rest of their lives and for their jobs, e.g. word processing, e-mail communication e.t.c.

In the context of this study therefore, utilization of ICT-based resources for library user education programme is the ability for an individual to have the knowledge of existing ICT opportunity and make use of this opportunity which will enhance effective and efficient retrieval services in the library. Examples of information and communication technology-based resources are, computer, Internet facilities, radio, cellular phones, CD-ROM, data-bases, electro-coping, smart board, projectors e.t.c. The situation on ground on the extent of utilization of ICT-based resources for library user education programmes in South-South colleges of education libraries is not fully embraced. This is because some of these colleges are still using the traditional chalkboard classroom teacher centred method.

It was observed by the researchers, that some students who graduated from college of education lack the knowledge for the use of the library, which is not good for the students and the society at large; this may be as a result of lack of utilization of ICT-based resources in the teaching of user education programmes. The extent of utilization of ICT-based resources in various college library user education programmes with particular reference to colleges of education in South-South Nigeria seems to have been unexplored. It is as a result of this problem that prompted the researcher to embark on this study, if not addressed on time, it will jeopardized the utilization of ICT-based resources in the teaching of user education programmes in the libraries under study.

\section{Purpose of the study}

The general purpose of the study was to assess the utilization of information and communication technology-based resources, for user education programmes of colleges of education in South, South Nigeria. Specifically, the following study sought to:

1. Identify the ICT-based resources available for user education programmes in SouthSouth colleges of education libraries.

2. Find out the extent of utilization of ICT-based resources for user education programmes in South-South colleges of education libraries.

3. Examine the challenges of the utilization of ICT-based resources for user education programmes in South-South colleges of education libraries

4. Suggest strategies for enhancing the utilization of ICT-based resources for user education programmes to South-South colleges of education libraries.

\section{Research questions}

The following research questions were formulated to guide the study:

1. What are the ICT-based resources available for user education programmes in SouthSouth colleges of education libraries?

2. To what extent is ICT-based resources utilized for user education programmes in SouthSouth colleges of education libraries?

3. What are the challenges to the extent of the utilization of ICT-based resources for user education programmes in South-South colleges of education libraries?

4. What are the strategies for enhancing the utilization of ICT-based resources for user education programmes in South-South colleges of education libraries? 


\section{Hypotheses}

The following hypotheses were tested for this study at 0.05 level of significance:

1. There is no significant difference between the mean responses of librarians and users on the extent of utilization of ICT-based resources for user education programmes in SouthSouth colleges of education libraries.

\section{Literature review}

Utilization, according to Atinmo (2000), is the ability to make effective and independent use of the resources and services in the library. This implies that the materials are in the appropriate format and language for use. It also extends to the frequency of usage of the materials and services and the concomitant utility, derived from the resources as observed by Adebayo (2007). This implies that such resources are organized in appropriate format and language for utilization.In a study of accessibility and use of library resources by undergraduates in Nigerian State University of Technology Oyewusi and Oyeboade (2009) observe that LAUTECH undergraduates appreciate the role of library to their studies. Therefore, university libraries, according to Olofinsawe and Oyeniyi (2010) should build strong collection of information resources in physical and digital formats to cater for knowledge requirements of their users. It is therefore necessary to survey the utilization of library resources by undergraduate students. Agbonlahor's (2006) investigation on motivation for use of information technology in universities revealed that the number of information technology related courses that lecturers had attended, significantly influenced their level of use of computers. More recently, in a study on predictive effect of academic qualification on perceived use of computer based libraries by staff in Nigerian university libraries, Uwaifo (2009) found out that there is a strong relationship between perceive use and actual usage of computer based libraries by the library staff.

From the above, therefore, one can define utilization in this sense to be the extent to which librarian and users make use of and benefit from the available resources and services in libraries. It can also mean the extent to which users make use of the resources of a library to meet their information needs. Use is the single criterion, which could be used to determine the reason for retaining a document within the collection of a library; and is essential in guiding the collection development effort of a library. The use of a library can be obtained from the demand of its items. In this study, the utilization of ICT-based resources for user education programmes in colleges of education libraries have become imperative if quality research has to be attained. Therefore there is the need for the utilization of ICT-based resources for user education programmes in colleges of education libraries by librarians and users in order to improve information system utilization in user education programmes.

User education programme

User education programmes also become necessary in view of the fact that most of the entrants into higher institutions especially in Africa are reportedly lacking in good reading habits and library skills, thereby necessitating the mounting of library user education programmes, by academic libraries, in order to make the library more user-friendly (Mchombu (2010); Aguolu \& Aguolu 2002). It is therefore important, to infer, that from available literature, it is deduced that the main essence of user education programmes in academic libraries, is to make library users more receptive and thus increase their competencies in independent library usage for academic excellence.

The failure of the individual to use the library skilfully and profitably according to Affia (2013) is a waste of library resources. It is also a waste of the time of professionals of the library 
as well as the teaching librarian. It therefore implies that, it is rather more cost effective, for libraries to invest in user-education, to ensure proper and effective utilization of their resources by users. Tiefel (2005) observes that user-education teaches how to make the effective use of the library and other information systems, including all other activities embarked upon to assist students become efficient information users. User education can be viewed from two categories of short and long term aims and objectives. The first category is concerned with the aim of helping students through their course and familiarizing them with finding information within a particular library. The second category (long-term objective) aims at providing students with an awareness and understanding in diverse areas including the principles and practices of learned communication, the structure of learned and specialist literature as well as internal and external information source (McElroy and Bate 2002).

The main purpose of library instruction programme is in proper guidance of library users towards a meaningful and purposeful use of resources (Fleming 2006). According to him to achieve this, libraries often embark on demonstration projects, case studies and establishment of cooperation with publishers, booksellers and suppliers of electronic products. 
Information and communication technology-based resources

Information and communication technology-based resources are the electronic appliances that process, organize and disseminate information in order to acquire a more satisfactory product Sesan (2001). The need for the development of ICT is a global resolution and has been a subject of great significance to all mankind (Olaofe, 2005). These technologies have become central in contemporary societies. Whether one is talking on phone, sending an e-mail, going to the bank, using a library, listening to sports coverage on the radio, watching the news on television; working in an office or in the field, going to the doctor, driving a car or catching a plane, one is using ICT. Information handling techniques, according to Okeesan (2003) are being modified with the introduction of information and communication technology, which increases speed, accuracy and efficiency in information. Information and communication technology need not be over stressed. It is a combination of computers, storage media which provide processing, storage and retrieval capabilities and telecommunications which have the capabilities of transferring and communicating data or information from one workstation to another (Nkanu 2008).

Information and communication technology refers to systems for producing, storing, sending and retrieving digital files (Barlet, 2002). The files can contain texts, sounds and images both still and moving. Ubegbu and Igwe (2006) also see ICT as a group of technologies that handle and manage information and records as well as transmitting information to whoever is in need of it. ICT is also the processing and maintenance of information and the use of all forms of computer and communication network to obtain information. Ndukwe et al (2005) stated that, the ICT is a revolutionary tool that enhances multifaceted development of a nation. Oketunji (2001) also in Adebisi (2009) described ICT as a term comprising the notion of the application of technology information handling such as information generation, storage, processing, retrieval and dissemination. The rapid development in the field of information and communication technology (ICT) has turned the world into a global village. The result is that the ways and means of information packaging and delivering have changed. Also, the information behaviour of users has begun to change at a fast rate.

\section{Library user education and information communication technology}

The convergence and constant change in the electronic world is challenging to academic instructional librarians (Loomis \& Fink, 2013). They therefore suggest that the principles of good instruction should apply regardless of what people are teaching. Graubart (2007) on his part discusses the development of online instruction programmes in different countries and highlighted the differences between Israeli and American academic libraries. She also describes library instruction programmes of seven Israeli academic libraries and discusses how students are taught to use online catalogue both in the classroom and at the reference desk.

There is also a special centre developed for scholars and librarians where classes are taught on how to find information on the Internet. Burrows (2015) reveal how librarians at the University of Australia deliver instruction on Internet use. According to Suarez (2002), many instruction librarians are presently using the web in addition to their regular teaching tools. This was against the practice in no-too-distant past when the only tools at one's disposal were overheads, whiteboards or blackboards and similar display items. In the opinion of the author, by mounting library instruction material directly onto a web page, it is possible to reach a potentially wider audience and to update the material more quickly whenever necessary. ICT-based resources have helped in various library activities since it came into existence. According to Islam and Islam (2006), ICT is used in various library activities which include acquisition, serials management, cataloguing and classification, circulation, audiovisual management, information storage, retrieval, reference and information services. Libraries have the following software TINLIB, Alice for Window, CDS/ISIS, e-granary e.t.c. Librarians interact with more groups and 
provide services for users with various characteristics. They need patience and initiative and a user-oriented approach. According to Agyen (2008), user education provides a platform where librarians introduce new students to the complexities of academic library facilities; familiarize users who have little or no information seeking skills at all with a broad range of library resources in order to develop library skills and educate them on how to find materials, using library catalogues, subject indexes, CD-ROMs and the Internet. Kaplowitz and Contini (1998) have undertaken a study of how librarians at the Louise M. Darling Biomedical Library University of Los Angeles (UCLA), developed a library user training programme based on Computer-Assisted Instruction (CAI) for 800 - 900 undergraduate biology students per year, who enroll in the Department's basic compulsory introductory course. Prior to the introduction of CAI, the librarians made use of laboratory manual for user education. With the introduction of CAI, records of class attendance showed an increase from 500 to 550, while it increased further to 730, with the combination of both laboratory manual and CAI. They came to the conclusion that the combination of CAI and laboratory manual is an effective and user-friendly way of offering user education. This study was on the use of Computer Assisted Instruction in library user education programmes, which the present study was based on, while this previous study was done in university, the present study was carried out in colleges of education.

Methodology

The design of this study is descriptive survey. The population of the study comprised of 62 librarians and 19,200 registered library-users. The sample size for this study was 62 librarians and 960 registered users, from the various libraries sampled for the study. The researcher used all the librarians because they were few and 5\% of the registered library users were used. The multiple stage sampling techniques was used to draw a sample of the registered users. One thousand and twenty-two (1022) copies of the questionnaire were distributed by hand to the respondents and were retrieved instantly on completion by the researcher and research assistants. The instrument for data collection for this research was the structured questionnaire, and observation checklist. The data collected was analyzed using mean scores, percentages and frequency tables. The responses were based on a 4 - point rating scale, a midpoint of 2.5 which is the criterion mean. The observation checklist was analyzed with percentage. The hypotheses formulated to verify research question two and four were analyzed with t-test, with a result at 0.05 level of significance.

\section{Results}

Research Question 1: What are the Information and Communication Technology-based resources available for user education programmes in South-South colleges of education libraries? 
Table 1:

Observation Checklist of Available ICT -Based Resources for User Education Programmes in South-South Colleges of Education Libraries.

NOTE: $N A=$ Not Available: $A N U=$ Available and not Utilize; $A U=$ Available and Utilize: $R=$ Remark; ASCOE=Akwa-Ibom State COE, AfahaNsit=ASCOE; BSCOE=Bayelsa State COE, Okpoama-Brass;CRSCOE= CrossRiver State

\begin{tabular}{|c|c|c|c|c|c|c|c|c|c|c|c|c|c|c|c|c|c|c|c|c|c|c|c|}
\hline & \multirow[t]{3}{*}{ ICT-based resour } & \multicolumn{19}{|c|}{ NAME OF INSTITUTION } & \multicolumn{2}{|l|}{ OVERAL } & \multirow[t]{2}{*}{$\mathrm{R}$} \\
\hline & & & ASCO & & & BFHC & & & $\mathrm{RSCOE}$ & & & $\mathrm{DSCOE}$ & & ESCOE & & & & FCOE & & & & & \\
\hline & & $\mathrm{AU}$ & ANU & NA & $A U$ & ANU & NA & $\mathrm{AU}$ & ANU & NA & $\mathrm{AU}$ & ANU & NA & $\mathrm{AU}$ & ANU & NA & $\mathrm{AU}$ & ANU & NA & $A U$ & ANU & NA & \\
\hline 1 & Smart Boards & & & $\sqrt{ }$ & & & $\sqrt{ }$ & & $\sqrt{ }$ & & & $v$ & & & & $\sqrt{ }$ & & & $\sqrt{ }$ & $0(0 \%)$ & $2(33.3 \%$ & 4(66.7\%) & NA \\
\hline 2 & CD-ROM & $\sqrt{ }$ & & & $\sqrt{ }$ & & & $\sqrt{ }$ & & & $\sqrt{ }$ & & & $\sqrt{ }$ & & & $\sqrt{ }$ & & & $6(100 \%)$ & $0(0 \%)$ & $0(0 \%)$ & $A U$ \\
\hline 4 & Databases & $\sqrt{ }$ & & & $\sqrt{ }$ & & & $\sqrt{ }$ & & & $\sqrt{ }$ & & & $\sqrt{ }$ & & & $\sqrt{ }$ & & & $6(100 \%)$ & $0(0 \%)$ & $0(0 \%)$ & $\mathrm{AU}$ \\
\hline 5 & Projectors & $\sqrt{ }$ & & & & $\sqrt{ }$ & & $\sqrt{ }$ & & & v & & & v & & & $\sqrt{ }$ & & & $5(83.3 \%)$ & $1(16.7 \%$ & $0(0 \%)$ & $\mathrm{AU}$ \\
\hline 6 & OPAC & & & $\sqrt{ }$ & & $\sqrt{ }$ & & $\sqrt{ }$ & & & & & $\sqrt{ }$ & & & $\sqrt{ }$ & & & $\sqrt{ }$ & $4(66.7 \%)$ & $1(16.7 \%$ & 1(16.7\%; & $A U$ \\
\hline 7 & MAR & & & $\sqrt{ }$ & & & $\sqrt{ }$ & & & $\sqrt{ }$ & & & $\sqrt{ }$ & & & $\sqrt{ }$ & & & $\sqrt{ }$ & $0(0 \%)$ & $0(0 \%)$ & $6(100 \%)$ & NA \\
\hline 8 & Facsimile (Telex) & & & $\sqrt{ }$ & & & $\sqrt{ }$ & & & v & & & $\sqrt{ }$ & & & $\sqrt{ }$ & & & $\sqrt{ }$ & $0(0 \%)$ & $0(0 \%)$ & $6(100 \%)$ & NA \\
\hline 9 & Telephone & $\sqrt{ }$ & $\sqrt{ }$ & . & $\sqrt{ }$ & & & $\sqrt{ }$ & & & $\sqrt{ }$ & & & $\sqrt{ }$ & & & $\sqrt{ }$ & & & $6(100 \%)$ & $0(0 \%)$ & $0(0 \%)$ & $\mathrm{AU}$ \\
\hline 10 & LAN & $\sqrt{ }$ & v & & $\sqrt{ }$ & & & $\sqrt{ }$ & & & $\sqrt{ }$ & & & $\sqrt{ }$ & & & $\sqrt{ }$ & & & $6(100 \%)$ & $0(0 \%)$ & $0(0 \%)$ & $\mathrm{AU}$ \\
\hline 11 & WAN & & & $\sqrt{ }$ & $\sqrt{ }$ & & & & & $\sqrt{ }$ & & $\sqrt{ }$ & a & & & $\sqrt{ }$ & & & $\sqrt{ }$ & $1(16.7 \%)$ & $0(0 \%)$ & $5(83.3 \%$; & NA \\
\hline 12 & $\begin{array}{l}\text { Video-conferencin } \\
\text { technology }\end{array}$ & & & $\sqrt{ }$ & & & $\sqrt{ }$ & & & $\sqrt{ }$ & & $\sqrt{ }$ & J & & & $\sqrt{ }$ & & & $\sqrt{ }$ & $0(0 \%)$ & $0(0 \%)$ & $6(100 \%)$ & NA \\
\hline 13 & E-mail & $\sqrt{ }$ & v & & $\sqrt{ }$ & & & $\sqrt{ }$ & & & v & & & v & & & $\sqrt{ }$ & & & $6(100 \%)$ & $0(0 \%)$ & $0(0 \%)$ & $\mathrm{AU}$ \\
\hline 14 & Radio & & & $\sqrt{ }$ & $\sqrt{ }$ & & & & & $\sqrt{ }$ & & & $\sqrt{ }$ & & & $\sqrt{ }$ & & & $\sqrt{ }$ & $1(16.7 \%)$ & $0(0 \%)$ & $5(83.3 \%$; & NA \\
\hline 15 & Electro-coping & & & $\sqrt{ }$ & & & $\sqrt{ }$ & & & $\sqrt{ }$ & & & $\sqrt{ }$ & & & $\sqrt{ }$ & & & $\sqrt{ }$ & $0(0 \%)$ & $0(0 \%)$ & $6(100 \%)$ & $A U$ \\
\hline 16 & Cellular phone & & & $\sqrt{ }$ & & & $\sqrt{ }$ & & & $\sqrt{ }$ & & & $\sqrt{ }$ & & & $\sqrt{ }$ & & & $\sqrt{ }$ & $0(0 \%)$ & $0(0 \%)$ & $6(100 \%)$ & NA \\
\hline 17 & Modem & $\sqrt{ }$ & & & $\sqrt{ }$ & & & $\sqrt{ }$ & & & $\sqrt{ }$ & & & v & & & $\sqrt{ }$ & & & $6(100 \%)$ & $0(0 \%)$ & $0(0 \%)$ & $\mathrm{AU}$ \\
\hline 18 & Printers & $\sqrt{ }$ & & & $\sqrt{ }$ & & & $\sqrt{ }$ & & & $\sqrt{ }$ & & & $\sqrt{ }$ & & & $\sqrt{ }$ & & & $6(100 \%)$ & $0(0 \%)$ & $0(0 \%)$ & $\mathrm{AU}$ \\
\hline \multirow[t]{2}{*}{20} & Flash Drives & $\sqrt{ }$ & & & $\sqrt{ }$ & & & $\sqrt{ }$ & & & $\sqrt{ }$ & & & $\checkmark$ & & & $\sqrt{ }$ & & & $6(100 \%)$ & $0(0 \%)$ & $0(0 \%)$ & $\mathrm{AU}$ \\
\hline & Total\% & $11\left(55^{\circ}\right.$ & $\% \quad 0(0 \%)$ & $9(45 \%)$ & $12(60 \%$ & $2(10 \%)$ & $6(30 \%)$ & $12(60 \%$ & $1(5 \%)$ & $7(35 \%)$ & $11(55 \%$ & $1(5 \%)$ & $8(40 \%)$ & $11(55 \%)$ & $0(0 \%$, & $9(45 \%)$ & $11(55 \%$ & 0 & $9(45 \%$ & & & & \\
\hline
\end{tabular}

COE, Akamkpa;DSCOE = Delta State COE, Agbor,ESCOE = Edo State COE, Ekiadolor; FCOEO= Federal COE, (Technical) Omoku 
The data presented in Table 1 shows that out of twenty ICT-based resources for user education programmes in South-South colleges of education libraries sampled,13(65\%) resources were available and utilized,7(35\%)were not available while none was available and not utilized.

The researcher also observed that at Akwa-ibom State COE, AfahaNsit, 11(55\%) ICTbased resources were available and utilized, while 9(45\%) were not available. In Bayelsa State COE, Okpoama-Brass, 12(60\%) were available and utilized, 2(10\%) were available and not utilized, while 6(30\%) were not available. At Cross River State COE, Akamkpa, 12(60\%) were available and utilized, 1(5\%) were available and not utilized, while 7(35\%) were not available. At Delta State COE, Agbor, 11(55\%) were available and utilized, 1(5\%) were available and not utilized, while 8(40\%) were not available. At Edo State COE, Ekiadolor, 11(55\%) are available and utilized, 0(0\%) were available and not utilized, while 9(45\%) were not available. At Federal COE, (Technical) Omoku, 11(55\%) were available and utilized, 0(0\%) were available and not utilized, while 9(45\%) were not available. From the result of Table 1, it was revealed that more than half of the listed ICT-based resources were available in the six colleges of education libraries under study.

Research Question 2: What is the extent to which ICT-based resources for user education programmes are utilized in South-South colleges of education libraries?

\begin{tabular}{|c|c|c|c|c|c|c|c|c|c|}
\hline & \multirow[t]{3}{*}{ Extent } & \multicolumn{4}{|c|}{ Status of respondents } & \multicolumn{2}{|c|}{ Overall } & \multirow[t]{3}{*}{$\mathbf{R}$} & \multirow[t]{3}{*}{$\mathbf{D}$} \\
\hline & & \multicolumn{2}{|c|}{ Librarians } & \multicolumn{2}{|l|}{ Users } & \multirow[b]{2}{*}{ Mean } & \multirow[b]{2}{*}{ SD } & & \\
\hline & & Mean & SD & Mean & SD & & & & \\
\hline 1 & $\begin{array}{l}\text { Online Public Access Catalogue } \\
\text { (OPAC) }\end{array}$ & 3.05 & .95 & 3.10 & .89 & 3.08 & .04 & $1^{\mathrm{ST}}$ & HE \\
\hline 2 & Reading articles of open access & 3.11 & .95 & 2.92 & .92 & 3.02 & .14 & $2^{\text {nd }}$ & HE \\
\hline 3 & Browsing of information & 2.94 & 1.07 & 3.01 & .91 & 2.97 & .06 & $3^{\text {rd }}$ & HE \\
\hline 4 & Bibliographic citation on internet & 2.98 & .90 & 2.94 & .92 & 2.96 & .03 & $4^{\text {th }}$ & HE \\
\hline 5 & Video-conferencing & 2.94 & .79 & 2.99 & .90 & 2.96 & .04 & $5^{\text {th }}$ & HE \\
\hline 6 & Library cooperation \& networks & 2.84 & 1.13 & 3.02 & .97 & 2.93 & .13 & $6^{\text {th }}$ & HE \\
\hline 7 & Video-conferencing & 2.71 & 1.05 & 3.01 & .96 & 2.86 & .22 & $7^{\text {th }}$ & HE \\
\hline 8 & Wide Area Network (WAN) & 2.74 & 1.05 & 2.91 & 1.00 & 2.82 & .12 & $8^{\text {th }}$ & HE \\
\hline 9 & Machine Readable Catalogue & 2.89 & .96 & 2.65 & .96 & 2.77 & .17 & $9^{\text {th }}$ & HE \\
\hline 10 & Document delivery & 2.82 & 1.00 & 2.69 & 1.01 & 2.75 & .10 & $10^{\text {th }}$ & HE \\
\hline 11 & Databases & 2.60 & 1.08 & 2.90 & .89 & 2.75 & .22 & $11^{\text {th }}$ & HE \\
\hline Gr & Mean & & .56 & 2.92 & .76 & 2.90 & & & \\
\hline
\end{tabular}

Key: SA-Strongly Agree, A-Agree, D-Disagree, SD-Strongly Disagree

The data presented in Table 2 reveals that the mean ratings of the respondents on the eleven (11) identified items on the extent to which ICT-based resources for user education programmes were utilized in South-South colleges of education libraries and had their mean values ranging from 2.75 to 3.08on a 4-point rating scale.Using the real limit of numbers, it can be observed that all the items had their mean value between 2.50-3.49. It can be deduced that the ICT-based resources listed in the table were utilized to high extent in South-South colleges of education libraries for user education programmes. 
The overall mean ranking showed that On-line Public Access Catalogue (OPAC) $(\bar{x}=3.08)$ ranked highest while Databases $(\bar{x}=2.75)$ ranked lowest on theextent to which ICTbased resources for user education programmes wereutilized in South-South colleges of education libraries. This table reveals that the extent of ICT-based resources were high in Online Public Access Catalogue (OPAC). The grand mean rating of librarians in utilization of ICTbased resources in Colleges of education libraries was $(\bar{x}=2.87)$ and the standard deviation was (0.56), the grand mean rating for users in utilization of ICT-based resources for user education programmes in colleges of education libraries was $(\bar{x}=2.92)$ and the standard deviation was (0.76) while the overall mean rating for librarians and users in utilization of ICT-based resources was $(\bar{x}=2.90)$ and the standard deviation was $(0.65)$.

Research Question 3: What are the challenges of utilization of ICT- based resources for user education programmes in South-South colleges of education libraries?

\begin{tabular}{|c|c|c|c|c|c|c|c|c|c|}
\hline \multicolumn{10}{|c|}{$\begin{array}{cccc}\text { Resourcesfor User Education Programme in South-SouthColleges of Education Libraries } & \text { Overall } & \text { Status of Respondents } & \text { D }\end{array}$} \\
\hline & & \multicolumn{2}{|c|}{ Librarians } & \multicolumn{2}{|l|}{ Users } & \multirow[b]{2}{*}{ Mean } & \multirow[b]{2}{*}{ SD } & \multirow[b]{3}{*}{$1^{\mathrm{ST}}$} & \multirow[b]{3}{*}{$\mathbf{A}$} \\
\hline & & Mean & SD & Mean & SD & & & & \\
\hline 1 & Poor funding & 3.31 & .65 & 3.37 & .73 & 3.33 & .69 & & \\
\hline 2 & Lack of Constant power supply & 3.36 & .89 & 3.19 & .89 & 3.29 & .89 & $2^{\mathrm{ND}}$ & $\mathbf{A}$ \\
\hline 3 & Lack of competent ICT Personnel & 3.28 & .94 & 3.25 & .97 & 3.27 & .95 & $3^{\mathrm{RD}}$ & $\mathbf{A}$ \\
\hline 4 & Non Implementation of ICT policy & 3.31 & .67 & 3.20 & .74 & 3.27 & .70 & $4^{\mathrm{TH}}$ & $\mathbf{A}$ \\
\hline 5 & Lack of infrastructural facilities & 3.28 & .96 & 3.24 & .95 & 3.26 & .96 & $5^{\mathrm{TH}}$ & A \\
\hline 6 & Frequent change in Technology & 3.20 & .79 & 3.20 & .74 & 3.20 & .77 & $6^{\text {th }}$ & $\mathbf{A}$ \\
\hline 7 & Hugh cost of Maintenance & 3.05 & 1.02 & 3.31 & .90 & 3.16 & .98 & $7^{\text {th }}$ & A \\
\hline 8 & Lack of interest by the management & 3.02 & .83 & 3.12 & .81 & 3.06 & .82 & $8^{\text {th }}$ & $\mathbf{A}$ \\
\hline 9 & Poor adaptation of older librarian & 2.90 & .91 & 3.20 & .90 & 3.02 & .92 & $9^{\text {th }}$ & $\mathbf{A}$ \\
\hline 10 & Lack of provision of ICT fertilities & 2.93 & .99 & 2.96 & 1.13 & 2.95 & 1.05 & $10^{\text {th }}$ & $\mathbf{A}$ \\
\hline 11 & Lack of access to computers & 2.91 & .89 & 2.99 & .94 & 2.95 & .91 & $11^{\text {th }}$ & A \\
\hline 12 & Lack of information & 2.97 & 1.03 & 2.82 & 1.07 & 2.91 & 1.05 & $12^{\text {th }}$ & $\mathbf{A}$ \\
\hline 13 & Lack of good location & 2.74 & .93 & 2.76 & .97 & 2.75 & .95 & $13^{\text {th }}$ & $\mathbf{A}$ \\
\hline 14 & Lack of conducive environment & 2.86 & 1.14 & 2.53 & 1.14 & 2.72 & 1.15 & $14^{\text {th }}$ & $\mathbf{A}$ \\
\hline & Grand mean & 3.08 & .59 & 3.09 & .67 & 3.08 & .75 & & \\
\hline
\end{tabular}

Key: SA-Strongly Agree, A-Agree, D-Disagree, Strongly Disagree

Table 3 shows the mean ratings of the respondents on the challenges to the level of utilization of ICT-based resources deployed for user education programmes in South-South colleges of education libraries. The results of the data analysis reveal that the respondents accepted that all the listed items were the challenges to the level of utilization of ICT based resources for user education programmes in South-South colleges of education libraries. This is because their entire overall mean were greater than the criterion mean of 2.50. Furthermore the table indication from the overall mean showed that poor funding $(\bar{x}=3.33)$ ranked highest, while lack of conducive environment $(\bar{x}=2.72)$ ranked lowest. The grand mean rating for the librarians in the challenges of utilization of ICT-based resources for user education programmes in colleges of education libraries was $(\bar{x}=3.08)$ and the standard deviation was $(0.59)$, the grand mean rating for users in the utilization of ICT-based resources for library user education programmes in 
colleges of education libraries was $(\bar{x}=3.09)$ and the standard deviation is $(0.67)$ while the overall mean rating for librarians and users mean was $(\bar{x}=3.08)$ and the standard deviation is (0.75). This table shows that poor funding was the major challenge of utilization of ICT-based resources for user education programmes in colleges of education libraries under study.

Research Question 4: What are the strategies for enhancing the utilization of ICT-based resources for user education programmes in South-South colleges of education libraries?

Table 4: Mean Ratings of Respondents on Strategies for Enhancing the Utilization of ICT-Based Resources for User Education Programmes in South-South Colleges of Education Libraries

\begin{tabular}{|c|c|c|c|c|c|c|c|c|c|}
\hline \multirow[t]{3}{*}{$\mathbf{s} / \mathbf{n}$} & \multirow[t]{3}{*}{ Strategies } & \multicolumn{4}{|c|}{ Status Respondents } & \multicolumn{2}{|c|}{ Overall } & \multirow[t]{3}{*}{$\mathbf{R}$} & \multirow[t]{3}{*}{ D } \\
\hline & & \multicolumn{2}{|c|}{ Librarians } & \multicolumn{2}{|l|}{ Users } & & & & \\
\hline & & Mean & SD & Mean & SD & Mean & SD & & \\
\hline 1 & Increase funding & 3.39 & .78 & 3.35 & .78 & 3.37 & .78 & $1^{\text {st }}$ & $\mathbf{A}$ \\
\hline 2 & Constant Power supply & 3.38 & .70 & 3.30 & .75 & 3.35 & .72 & $2^{\text {nd }}$ & $\mathbf{A}$ \\
\hline 3 & Provision of infrastructural facilities & 3.33 & 1.01 & 3.32 & .99 & 3.33 & 1.00 & $3^{\text {rd }}$ & $\mathbf{A}$ \\
\hline 4 & Implementation of ICT policy & 3.34 & .68 & 3.30 & .69 & 3.32 & .68 & $4^{\text {th }}$ & $\mathbf{A}$ \\
\hline 5 & $\begin{array}{l}\text { Availability of competent ICT } \\
\text { personnel }\end{array}$ & 3.14 & .92 & 3.29 & .85 & 3.20 & .90 & $5^{\text {th }}$ & $\mathbf{A}$ \\
\hline 6 & Provision of ICT facilities & 3.19 & 1.06 & 3.16 & 1.09 & 3.18 & 1.08 & $6^{\text {th }}$ & $\mathbf{A}$ \\
\hline 7 & More use of the library & 3.08 & 1.10 & 3.13 & 1.14 & 3.10 & 1.11 & $7^{\text {th }}$ & $\mathbf{A}$ \\
\hline 8 & $\begin{array}{l}\text { Acceptance of new technology by } \\
\text { older Librarian }\end{array}$ & 3.00 & 1.05 & 3.20 & 1.03 & 3.09 & 1.04 & $8^{\text {th }}$ & $\mathbf{A}$ \\
\hline 9 & More access to computers & 3.07 & 1.04 & 2.95 & 1.00 & 3.02 & 1.02 & $9^{\text {th }}$ & $\mathbf{A}$ \\
\hline 10 & Provision of conducive environment & 3.06 & 1.09 & 2.93 & .94 & 3.00 & 1.03 & $10^{\text {th }}$ & $\mathbf{A}$ \\
\hline 11 & Provision of good Location & 2.90 & .86 & 3.05 & .79 & 2.96 & .84 & $11^{\text {th }}$ & $\mathbf{A}$ \\
\hline 12 & Provision of Information & 2.89 & .97 & 2.95 & .94 & 2.91 & .96 & $12^{\text {th }}$ & $\mathbf{A}$ \\
\hline 13 & Interest of Management on ICT & 2.77 & 1.23 & 3.02 & 1.18 & 2.87 & 1.21 & $13^{\text {th }}$ & $\mathbf{A}$ \\
\hline \multirow[t]{2}{*}{14} & Moderate cost of maintenance & 2.88 & 1.26 & 2.63 & 1.09 & 2.78 & 1.19 & $14^{\text {th }}$ & $\mathbf{A}$ \\
\hline & Grand Mean & 3.10 & .65 & 3.11 & .43 & 3.10 & .53 & & \\
\hline
\end{tabular}

Key: VA-Very Appropriate, A-Appropriate, LA-Less Appropriate, NA-Not Appropriate

Table 4 shows the mean ratings of respondents on strategies to enhance the utilization of ICTbased resources for user education programmes in South-South colleges of education libraries. The results of the data analysis show that the respondents agreed that all the fourteen listed strategies were required strategies to enhance the utilization of ICT-based resources for user education programmes South-South collegesof education libraries, since their mean score was above (2.50) the criterion mean. Also, the overall mean rating showed that increased funding $(\bar{x}=3.37)$ ranked highest, while moderate costof maintenance $(\bar{x}=2.78)$ ranked lowest as strategies for enhancing the utilization of ICT-based resources for user education programmes in South-South colleges of education libraries. The grand mean rating of librarians on the strategies for enhancing the utilization of ICT-based resources for user education programmeswas $(\bar{x}=3.10)$ and the standard deviation is $(0.65)$, the grand mean rating of user on the strategies for enhancing the utilization of ICT-based resources for user education programmes in colleges of education libraries was $(\bar{x}=3.11)$ and the standard deviation was $(0.43)$ while the overall mean 
rating for librarians and users on the strategies for enhancing the utilization of ICT-based resources for user education programmes in colleges of education libraries was $(\bar{x}=3.10)$ and the standard deviation was (0.53). The result of this table revealed that to increased funding was the highest strategy for enhancing the utilization of ICT-based resources for user education programmes in colleges of education libraries under study.

\section{Hypothesis}

Ho1: There is no significant difference between the mean responses of librarians and users on the extent of utilization of ICT-based resources for user education programmes in South-South colleges of education libraries

The data testing hypotheses two is presented in table 5.

Table 5: t-Test Analysis of the Mean Ratings of the Responses of Respondents on the Extent of Utilization ICT-Based Resources for User Education Programmes in South-South Colleges of Education Libraries

\begin{tabular}{|c|c|c|c|c|c|c|c|c|c|}
\hline $\mathbf{S N}$ & Groups & $\mathbf{X}$ & SD & $\mathbf{N}$ & DF & $\begin{array}{l}\text { Std. } \\
\text { Error }\end{array}$ & t- Cal & $\begin{array}{l}\text { Level } \\
\text { Sig. }\end{array}$ & Rmk \\
\hline \multirow[t]{2}{*}{1.} & Librarians & 2.60 & .98 & 82 & & & & & \\
\hline & & & & 928 & 988 & 0.123 & 2.219 & $\mathrm{P}<0.05$ & $\mathbf{S}$ \\
\hline 2. & Users & 2.87 & 0.92 & & & & & & \\
\hline
\end{tabular}

Dependents variable $=$ extent of utilization of ICT-based information resources

The t-test analysis presented in Table 10 showed that the $t$-calculated (t-cal) value of 2.219, with $\mathrm{P}>0.05$ indicated that there was significant difference. Therefore, the null hypothesis was rejected showing that there was significant difference between the mean responses of librarians and users on the extent of utilization of ICT-based resources for user education programmes in colleges of education libraries.

\section{Summary of findings}

The following findings were made from the data analyzed for the study:

1. The ICT-based resources for user education programmes available in the six colleges of education libraries were thirteen (13) which was sixty-five percent (65\%) was available and utilized for the awareness and utilization of ICT-based resources for user education programmes in the South-South colleges of education libraries, while seven (7) which was thirty five percent (35\%) was not available

2. With regard to the extent of utilization of ICT-based resources for user education programmes in Akwa-Ibom State College of Education AfahaNsit, Bayelsa State College of Education Okpoama-Brass, Cross River State College of Education Akamkpa, Delta 
State College of Education Agbor, Edo State College of Education Ekiadolor and Federal College of Education (Technical) Omoku, The use of Online Public Access Catalogue was ranked highest while Databases was ranked lowest as extent of ICT-based resources utilized for user education programmes in South-South colleges of education libraries

3. Also, the seven major challenges of utilization of ICT-based resources for user education programmes that were identified were poor funding, lack of constant power supply, lack of competent ICT personnel, non-implementation of ICT policy, and lack of infrastructural facilities, and frequent change in technology and high cost of maintenance.

4. The librarians and users in the six colleges of education in the study also proffered seven major strategies for enhancing the effective utilization of ICT-based resources in library user education programmes of ICT-based resources for library user education programmes. They were increased funding, constant power supply, provision of infrastructural facilities, implementation of ICT policy, availability of competent ICT personnel, provision of ICT facilities and more use of the library.

5. The result of hypothesis two tested shows that the hypothesis was rejected because there was significant difference between the mean responses of librarians and users in the extent of utilization of ICT-based resources for user education programmes in SouthSouth colleges of education libraries.

\section{Recommendations}

In order to improve on the awareness and utilization of ICT for library user education programmes in colleges of education libraries and other types of libraries, this study makes the following recommendations:

1. The colleges of education authorities should embark on capacity building programmes in terms of training and re-training of librarians on ICT awareness and extent of utilization. This should be made a regular feature inform of conferences, seminars, workshops and on the job training to enhance the performance of the librarians on ICT utilization to access library resources.

2. The national policy on ICT in higher institutions including the colleges of education should be properly implemented. This would enable the higher institutions, especially the colleges of education to fully embrace the utilization of ICT, for training of their librarians to be relevant and effective in joint services, with other institutions of the world.

3. Also, the colleges of education authorities should provide constant power supply through independent power providers or gas generators in colleges of education. These will in no doubt aid the effective utilization of ICT for library user education programmes in colleges of education libraries.

4. The colleges of education should review their recruitment/enlistment requirement and requisite qualification for librarians to include knowledge in ICT utilization. This would aid the librarians and users in the ease of utilization of ICT-based resources for the user education programmes.

5. The colleges of education authorities should make ICT-based resources available for user education programmes in South-South colleges of education libraries. This 
would definitely enable librarians and users have quick access to ICT-based resources.

6. The colleges of education libraries that have ICT-based resources should ensure proper maintenance of these ICT resources to enable the librarians and library users always have access to functioning ICT-based resources in colleges of education libraries.

\section{Conclusion}

The utilization of ICT-based resources for user education programmes in South-South colleges of education occupies a central position not only in South-South colleges of education libraries, but also all modern colleges of education libraries. This could be across the globe for effective and efficient performance of librarians in ICT-based information resources for library user education programmes. This study set out to examine the utilization of information and communication technology-based resources for library user education programmes with regard to colleges of education libraries in South-South zone.

\section{References}

Adebayo, O. (2007). Availability and utilization of material resources as correlates of student's learning outcome in Secondary school history: A case study of some selected secondary schools in Oluyole Local Government Area of Oyo State. Unpublished M.Ed. Project, University of Ibadan.

Affia, G. E. (2013). Promotion of reading in academic communities. African Journal of Academic Librarianship 1 (2) 64-70.

Aguolu, C. C. \& Aguolu L. E. (2002).Libraries and Information Management in Nigeria: Seminar essays on themes and challenges. Maiduguri: Educational Information Service. (14) 11.

Agyen-Gyasi, K. (2008). User Education at the Kwame-Nkrumah University of Science and Technology (KNUST) Library: Prospects and Challenges; Library Philosophy and Practices. (3) 23-26.

Atinmo, M. I. (2000). Availability and accessibility of Library resources for the visually handicapped in Nigeria: The way forward, Journal of Association of Librarians for the Visually Handicapped 1(1):15-22.

Barlet, A. (2002). ICT and integrated pest management (IPM) FAO and filed schools; Bringing integrated Pest management to the grassroots in Asia, Rome, FAO, 18.

Burrows, T. (2015). Educating: for the internet in an academic library: the scholars centre at the University of Western Australia Education of Information skills Journal of instructional psychology 30(2), 82.

Clark, S.O. (2009). Fundamentals of Library Science, Warri: COEWA Publishers.

Edoka, B. E. (2000). Introduction to Library Science, Onitsha; Palma Publishing p. 164-168.

Fleming, H. (2006). User education in academic libraries in the United Kingdom. British Journal of Academic librarianship 1(1).

Graubart, M. (2007). Orientation sessions in Isreali academic libraries. Research Strategies 13 (summer) 165-175.

Islam, S. O. and Islam, T. N. (2006). Information literacy for libraries. Library philosophy and practice. Available: http://libr.unl.edu:2000/LPP/hooks.htm. 
Kaplowitz, J. and Contini, J. (1998). Computer-assisted instruction: is it an option for bibliographic instruction in large undergraduate survey classes. College and Research Libraries 59 (1) 19-27

Loomis, A. and Fink, D. (2013). Instruction: gateway to the visual library in Zick, P. In The Virtual library: visions and reality. Westport: Meckler, 47-69.

McElroy, A. R. and Bate, J. L. (2002). User education for life? Library Review 3-10

Mchombu, K. (2010). Which way African Librarianship? IFLA Journal. 17 (1): 26.

Ndukwe, C. P. (2005). Emerging Tools in the Provision of Library and Information Service in the $21^{\text {st }}$ Nigeria. The Research Librarian, 1(1), 16-27.

Nkanu, W. O. (2008). Utiliazation of information and communication technology facilities in Nigeria University libraries: International journal of information and communication technology, (1), 1-6.

Okeesan, F. A. (2003). Basic principles and practice of librarianship, Nigeria; PSG -Franc publications; 25-32.

Oketunji, I. (2001). Education of libraries in an electronically oriented society, Paper presented at the Cataloguing, classification and indexing section of the Nigeria Library Association seminars/Workshop on software choice parameters for cataloguing Nigerian Libraries, held at the conference Hall of Ondo State Branch of the National Library of Nigeria, Akure, October 22-27.

Olaofe, I. A. (2005). Nigerian educational emancipation: roadmap from crisis to resurgence. Faculty of education seminar series, 2, (1) Ahmadu Bello University, Zaria. 22

Sesan, E. (2001). Information and communication technology: development opportunities and the role of youths. This Day newspaper, 7, 2265, (25) July 5, 8.

Suarez, D. (2002). Designing the web interface for library instruction tutorials using Dreamweaver, fireworks and course builder. Information Technology and Libraries, 21(3), 192.

Tiefel, V. (2005). Library user education: examining its past, projecting its future. Library Trends 44(2), 320.

Tinio, V.I. (2002). ICT in Education. United Nations Development Programme. Bureau for Development Policy. New York. Accessed June, 24. http://www.eprimers.org.

Uhegbu, A. N. and Igwe, K.I. (2006).Information and communication technology (ICT) and the Millennium development goals. The information technologist; 3 (2) 97-100.

Zodwa, E. (2013), Resistance to Change in Libraries: Application of Communication Theories. Portal: Libraries and the Academy 3(1), 69-78 